\title{
EQUILIBRIUM
}

Quarterly Journal of Economics and Economic Policy

VOLUME 9 ISSUE 1, 2014

p-ISSN 1689-765X, e-ISSN 2353-3293

www.economic-policy.pl

Ząbkowicz A. (2014), Organized Economic Interests and European Integration: The Question of (neo)corporatism, "Equilibrium. Quarterly Journal of Economics and Economic Policy", Volume 9, Issue 1, pp. 7-20, DOI: http://dx.doi.org/10.12775/EQUIL.2014.001

\section{Organized Economic Interests and European Integration: the Question of (neo)corporatism}

\section{JEL Classification: $B 52, P 16$}

Keywords: economic interests, channels of access, European Union

\begin{abstract}
When economic development is considered, political economy is at stake; in this perspective growth or counter-growth forces operate within the institutional framework. The analysis focuses on corporatist forms of social dialogue in the international environment of the EU and within the European structures. First, the notion of corporatism as opposed to other institutionalized channels of access is explained. Then, the paper presents corporatist forms at the national level under change. Next, it deals with interest coordination at the European Commission level. The paper concludes that an erosion of corporatist forms is visible; no embracing pattern in the EU should be expected instead; on the contrary, increasing fragmentation of lobbying is observed.
\end{abstract}

\section{Introduction}

When economic development is considered, political economy is at stake. Growth or counter-growth forces operate within the institutional framework. A large body of scholarly work is devoted to the interplay of interests and to the forms of their representation in the context of the European Union. The

(C) Copyright Institute of Economic Research \& Polish Economic Society Branch in Torun Date of submission: March 30, 2013; date of acceptance: November 7, 2013

*Contact: holic@op.pl, Instytut Nauk Ekonomicznych, Polskiej Akademii Nauk, Nowy Świat 72, 00-901 Warszawa, Poland 
research is in progress for many various reasons. Firstly, Europeanization has proceeded fast, and is still developing, and while constitutionalization of decision-making and institutionalization of policy processes is carried on, private actors need to define their interests and find their roles in the dynamic environment. Secondly, developing European structures offer new access points for organized interests. According to the Treaty on the European Union, the European institutions "shall maintain an open, transparent and regular dialogue with representative associations and civil society" (EU 2010, Art.11.2). Interest representations have been employed by the European Commission and the Council of Ministers inter alia to improve the legitimization of their decision making, as well as their image in terms of democracy. And, last but not least, the increasing regulatory functions of the European Union (EU) in the process of market making are of great interest for many industrial and financial groups who seek access to decision-making procedures.

Which forms of interest representation are particularly eminent in the EU? To what extent is the Treaty article quoted above coherent with the move to market and economic liberalization under agreements on the Single Market and on Economic and Monetary Union? These are the set-off questions of this piece of work.

\section{Methods and Contents of the Article}

In the research, the approach of institutional and political economy has been applied. Rules and structures make actors coordinate and intermediate their interests matter. This is a perspective of the theory of rent seeking, economic theory of democracy, theory of regulation, economic theory of bureaucracy, etc. The focus are corporatist forms of social dialogue in the international environment of the EU and within the European structures. Is this device of institutionalized inclusion of organized interests in the policy and law making process sustainable, both in member countries and in the Community? Is the recovered corporatism a solution to new problems of global governance? Is any embracing pattern of lobbying European Commission recently emerging? First, the notion of corporatism as opposed to other institutionalized channels of access is explained. Then, the paper presents corporatist forms at the national level under change. A brief presentation of scholarly discussion going on neo-corporatism follows. The third section deals with consultation, coordination and intermediation at European Commission (EC) level. The paper concludes that the erosion of collective corporatist forms and the in- 
creasing fragmentation of lobbying arise old questions about rent seeking and democracy.

\section{Institutionalized Inclusion of Organized Interests in the Policy-making Process}

Institutional-evolutionary political economy shares interest in power relations with political science and, to much lesser extent, with some sociological theories (e.g. social movements literature). On the basis of this interdisciplinary research, the notion of channels of access of private and social actors to public authorities can be reconstructed. "Channel" means both a stream and boundaries (or form). The notion refers to the flow of information, and the current is existent as long as there is a supply side and a demand side. In the EU context, on the supply side private or social actors offer goods (expertise and specific information) in order to influence the decision making. They are engaged in collective action of various organizational shape and of various degree of cooperation. Here, representative national associations and so called Eurogroups along with commercial lobbyists and business-established bureaus, as well as social movements, are active (Michalowitz 2004, pp.77-78). On the other side, the EU institutions (the European Parliament, the Commission, the Council of Ministers) demand expertise which they are not able to produce themselves. Interests can gain access if they are simultaneously demanded by the targeted European institution (Charrad 2007, p. 9).

The form of this exchange is under debate. Most often it is labeled as pluralism, corporatism, or possibly (policy) networks, but scholars' definitions differ (see Hassel 2010, p.158; Ottaway 2001, pp.3-5; Charrad 2007, pp.1011; Cini 2007, p. 275). The debate goes on whether these terms are transferable to the EU level from the national level, where they have been originally developed, and to what extent (Streeck, Schmitter 1991; Michalowitz 2004).

Before we set off with defining forms of this kind of intermediation and exchange, some remarks on basic notions may be required. It can be assumed that all the forms named above are contained in the concept of lobbying in a broad sense and having skipped negative connotations the term has acquired (see Charrad 2007, pp.2-3). In this paper, such activities mean communication oriented exclusively to those who are either opinion- or decision-making in areas that are important for organized interests. Which areas of interest are at stake? Economic interests in protection against foreign competition, in public aid and in various regulations (of taxes, capital and stock, budgets and para-budgets, etc) are to be mentioned first. However, since the 1970 s new social movements representing so called civil society 
developed rapidly across Europe. The NGOs movement shares interest in equity and justice that characterized socialist movements in the past, but adds new concerns, particularly environmental ones. The notion of organized interests is far from being precise. In my view, they can be defined as community of interests or views which uses its representatives to address public body (legislature, government, supranational institution) with their own postulates or arguments in aim to change or conserve rules of the game (see Cini 2007 , p. 275$)^{1}$. What are then the social arrangements and institutional devices of inclusion of organized interests in policy- and law-making?

Pluralist pattern of lobbying relies on profit-oriented intermediaries between those who make rules and those who have to subordinate. Originally, it was government, on the one side and (mainly) business on the other. This model was developed and widely practiced in the $\mathrm{USA}^{2}$. The core of it is constituted by lobby firms commissioned to represent specific (mostly business) interests, which rely on both formal and informal exchange, carried out on behalf of their customers. Many of them are busy in Brussels.

Associations are at the core of the corporatist system. These "corporate actors" share resources and, basically, goals as well. They are founded on membership, and their activities are based on elaborate decision-making procedures (Hassel 2010, p. 154). The Netherlands' or Poland's tripartite Social-Economic Commissions are examples of such pattern of lobbying. Apart of governmental representatives, the two other parties within the Commission consist of registered organizations which were awarded the right to represent major economic interests. They are peak interest organizations with extensive coverage, since they coordinate numerous associations of two different categories, clearly cut off from each other: the employers party (business representation) and the employees party (trade unions) respectively.

Corporatist institutions are formal and empowered, and sometimes they are regarded to be a quasi-public authority. As Anke Hassel $(2010$, p. 158) puts it, "highly centralized organized interests have been charged with functions that reach much beyond the status of lobby. [...] They not only sit on supervisory boards of public or quasi-public agencies but also selfadminister welfare functions whose budgets are underwritten by the state."3 It is being stressed, that the partners act ,not as lobbies working in the corridors of power but as participants at the table where decisions are made" (Ot-

\footnotetext{
${ }^{1}$ Sometimes "interests" refer to individual firms active in political market as well.

2 The concept stems from the theoretical point of view held by many social scientists with regard to American politics, known as "pluralist theory" (Johnson 2005).

${ }^{3}$ That is, sitting in supervisory/governing boards of such welfare state institutions as universities, schools, hospitals, etc. (Hassel 2010, pp. 157,158).
} 
taway 2001, p. 7). Corporatist system of negotiations and agreements is administered by the state and operates beyond parliament although the outcome often wins parliamentary approval. Corporate actors are involved in social and economic councils, in supervisory boards of public agencies, and in various advisory committees in many European countries (Germany, Sweden, Austria, etc.). Accordingly, national peak associations gain access to European policy making with help of national ministries of each member state and the European Council of Ministers, as well as via numerous formal consultative committees and sub-committees at EU level (Hassel 2010, pp. $157,158,162)$. They constitute sector or cross-sector umbrella of European federations, often referred to as Eurogroups. European employers' and business umbrella representation (CEEP and BusinessEurope, former UNICE) along with labour representation (ETUC) enjoy a privileged status of social partners. In practice, it means regular meetings and information exchange with the European Commission with the option of common legislative initiatives (Nugent 2012, p. 316; Cini 2007, p. 282).

In a nutshell, corporatism is a tripartite setting of public, social and private/business representations. Traditionally, interests are represented by peak organizations with extensive coverage, since they coordinate numerous associations. Due to the character of agents involved this is a centralized and formalized social bargaining.

Thus, corporatism is a form of representation and participation which is clearly different from lobbying done by numerous and dispersed commercial intermediaries; it also differs from collective action of more "fluid" actors such as social movements or ad-hoc coalitions. Having the latter in mind, some authors observe a pattern of interest intermediation which is labeled as policy networks. While corporate actors share resources and are structured and organized, social movements share goals, but not necessarily resources, and act without a definite organizational structure. While centralized organized interests enjoy institutionalized access points to policy-making process mentioned above, non-governmental organizations (NGOs) gain access mainly by using "voice strategies", such as public opinion campaigns, media events, demonstrations and so on (Hassel 2010, p. 154). Their cooperation is much looser, and is perceived rather as ad-hoc functional problem solutions, when "resources are dispersed over several public and private actors and these actors have to cooperate if they wish to be effective in policy-making" (Charrad 2007, p. 11, see Eising, Kohler-Koch 1999, Boerzel 1998). The actors sharing these characteristics sustain an increasing percentage of organized interests lobbying the EU institutions.

In short, all forms of interest representation which have been originally developed at the national and sub-national levels are present in the EU. Speaking on "dialogue with representative associations and civil society" as 
well as on institutional channels of access to the EU institutions, we mean forms of activities just described and targeted as above. Is corporatism the most eminent among them?

\section{Corporatism: Evolution or Extinction?}

Corporatism is about functional economic interests, basically represented by associations of business and labour. Their significance at the EU level stems from their size, organizational capacity and long-standing structures which evolved under national corporatisms.

The history of capitalism can be seen as a sequence of co-opting new organized interests: from syndicalism to corporatism, from classical corporatism to neo-corporatism, and from neo-corporatism to global corporatism. The $19^{\text {th }}$ century and early $20^{\text {th }}$ century created the power of corporations, cartels and agricultural syndicates. Industrialization and mass production induced development of market relations in the society, and market economy expanded internationally thanks to gold standard (Polanyi 2001). It provided unprecedented economic power to some producers and employers and, in retort, led to self-organization of labour interests. Corporatism was invented in the 1920's as a response to the growth of labour movement which, affiliated with the socialist and communist parties, had the potential to threaten the political status quo. Corporate groups were defined essentially in terms of social class, with labour organizations and business councils supplemented by associations of farmers and other occupational groups as the key components of the system (Ottaway 2001, pp. 3, 5). Originally, corporatist system was connected to $20^{\text {th }}$ century fascism and had in its core the advocacy of an institutional relationship between a strong and dominant state and interest representation. After the WW II corporatism was reinvented as a device to promote social peace by giving the labour movement a role in governance and to attain a high level of macroeconomic performance within the Keynesian framework (Ottaway 2001, p. 5; Molina, Rhodes 2002, p. 307). At this stage, being labeled "neo-corporatism", it was perceived inter alia as a program for the resolution of employment issues, namely wage bargaining and labour market regulation (Molina, Rhodes 2002, p. 305; Rymsza 1998). This trait became especially prominent when in the 1970's governments sought agreement of employers and trade unions to incomes policies designed to stem rising rates of inflation.

The vision became distorted in the 1980's, which witnessed a "move to the market", and in the early 1990's, when the concept of corporatism fell out of favour. The economic conditions changed. Dissatisfied with poor lev- 
els of economic performance in the 1970's, the governments tried to boost their economies introducing programs of market liberalization and deregulation, as well as changing regulatory regimes. This neoliberal "revolution" confronted economic actors (business and finance first of all) with new challenges and opportunities. The member states of European Community agreed in 1985 to create a single continental market, which became reinforced by the Maastrich Treaty in 1992, and with a common currency for most of the EU member-countries in 1999. This move to the market changed thoroughly the policy making, as well as doing business. The Keynesian policy making, which required a decent portion of trade and capital controls to be effective, was consequently abandoned. Fordist industrial organization, related to the idea of mass consumption and based on the assumption that worker's wages are decent enough to buy enough, was confronted with price inflation, which made real incomes significantly lower. Due to financial liberalization, over time industrialization was replaced by financialization. In accordance with market philosophy, welfare state was getting retrenched. In short, due to the policy reforms, as well as technological change, Keynesian policy making, Fordist industrial organization and welfare systems, which were believed to constitute foundations of neo-corporatism, began to erode (Molina, Rhodes 2002, pp. 306, 309).

Whether there was a return to neo-corporatism since the late 1990's is under debate. Numerous writers proclaimed the end of the neo-corporatist episode. Technological change, it was argued, undermined the foundations of traditional European industrial relations and, hence, corporatism is eroded from below. Reforms "from above" resulted in looser labour markets and, generally, caused a shift in the balance of power from trade unions to employers. As a result, tripartite bargaining seems to be less useful and out-ofdate (Gobeyn 1993).

Nevertheless, some scholars argue that changing economic conditions revealed the adaptability of corporatism, and that a "neo-corporatism 2" emerged which, however, requires a new understanding (Molina, Rhodes 2002). According to this view, in the late 1990's another major move, namely the shift to European Monetary Union (EMU), challenged practicing corporatism at national level, however the challenges posed by EMU were cushioned by national corporatist solutions. The Maastricht Agreement "institutionalized" the shift from Keyensian economic policy to a nonaccommodating monetary regime. The conditions imposed on access to EMU made a budget-deficit reduction a central feature of member-state policy and, in consequence, have limited the resources available for welfare state. For the sake of common currency, monetary regime entails the loss of independent national exchange rate policies and the focus on an inflation target, which makes wage costs a key component of macroeconomic adjust- 
ment. Respectively, new social pacts made the issue of pay restraint central in the early phases of EMU, supplemented by labour market flexibility and the restructuring of social security programs (Molina, Rhodes 2002, p. 315). The authors conclude, "In those cases where EMU and its stringent conditions posed serious challenges to the economy (this is the case of peripheral countries: Italy, Spain, Greece, Portugal, and Ireland) social pacts have also served to legitimize and to make more socially acceptable the sacrifices required by adjustment to the single currency." (Molina, Rhodes 2002, p. 316).

Thus, the very idea of social bargaining and concertation was still at work in the 1990's though its form had changed. What are the traits that differentiate it from past forms and experiences? The point is, according to Ebbinghaus and Hassel (2000), that the centralization and extensive coverage of the peak interest organizations of capital and labour may not be the sine qua non of successful corporatism . Oscar Molina and Martin Rhodes (2002, p. 316) argue that understanding "neo-corporatism 2" "requires greater emphasis on the goals and strategic behavior of actors than on institutions and systemic variables". Institutions change and become less formal; in effect since the 1990's social pacts and more fluid organizational forms, like macro-policy concertation $^{4}$ are at stake. Structures and actors of the new types of corporatist concertation should be understood in terms of networks, rather than of centralization (Molina, Rhodes 2002, p. 326). In opposition to excessively structural-functionalist interpretation of corporatism in the 1980's and 1990 's, the phenomenon should be seen as a process, rather than a specific form of interest intermediation. As long as political will of unions and employers is in place, coordinated bargaining in spite of "organized decentralization" "might prove to be a 'new' (but unusual) form of neo-corporatism, in which representative organizations accept a role of restraining their members, a role that would also prove more appropriate for an era of global restructuring and monetary discipline than a disorganized and decentralized neoliberal alternative.'(Molina, Rhodes 2002, p. 312) Was it a return to neocorporatism indeed? Did corporatism survive move to market? Molina and Rhodes answer "Yes", if it is seen as a process of decision making rather than a system alone.

According to Marina Ottaway's interesting view, corporatism not that much survived but rather was reinvented once more as "global" corporatism. The changes in the international economy in the 1980's and the 1990's, usually meant under the term "globalization", consisted inter alia of the increased role of international organizations (UE, WTO, IMF, IBRD), the ex-

\footnotetext{
${ }^{4}$ Macro-policy concertation refers to forms of routinized bargaining between governments, employers, and trade unions. Social pacts used to be based on peak-level concertation, to adapt to new economic policy challenges (Molina, Rhodes 2002, p. 306 and 309 respectively).
} 
pansion of transnational corporations and the growth of the NGOs sector. These three groups of actors fill the tripartite setting of "global" corporatism. According to Ottaway, it was reinvented for the same reasons as "national" corporatism was, the one which had sought to co-opt the power of social movement, which is trade unions affiliated with political parties, and to dilute its influence through the formation of tripartite councils. Recently, "international institutions and transnational corporations are challenged by NGOs, particularly by the emergence of transnational NGOs networks that have proven quite skillful at pushing new agendas and at stopping or delaying projects of which they disapprove.[...] new NGOs are challenging the new global trends that allowed them to emerge in the first place, much as labour movement challenged the socioeconomic consequences of the process of industrialization of which it was a product."(Ottaway 2001, p. 5). Global corporatism is an attempt of institutionalized inclusion of this new social movements, and has both a defensive character and a progressive aspect. On the one hand, creating points of access to international organizations (e.g. the $\mathrm{EU}$ ) is an attempt to diffuse the "anti-" and "alter-global" criticism by coopting more moderate groups. On the other hand, inclusion, dialog and exchange with "partners" (in rhetoric of international organizations) can provide innovative solutions for new problems.

Is this political invention sustainable? Is the recovered corporatism a solution to new problems of global governance? Ottaway seems to be skeptical (Ottaway 2001, pp. 15-17). She points to the glaring weaknesses of the tripartite global setting. Firstly, NGOs are not representative organizations and seem to be highly selective in whose interests they represent. Secondly, international organizations are divided, and they still play a less significant role than national governments. Thirdly, the relations in tripartite councils are far from balanced. Ottaway comments, “...the World Bank and a network of NGOs are not equal partners, and throwing large corporations into the mix makes the disparities even more obvious."(Ottaway 2001, p.16) The problem becomes really grave provided such tripartite council or commission has the power to impose and enforce standards. Empowering such deficient and non-representative bodies is a major problem according to Ottaway, as well as their formalization is. Ottaway (2001, pp. 16-17) argues, "Groups are included in corporatists arrangements on the basis of their influence at the time. But in any system that provides a formal role for some organizations, those already included have a vested interest in perpetuating their position and in keeping possible new entrants out.[....] The more official tripartite arrangements become, the more serious the distortion can become." Consequently, pluralist pattern of lobbying seems to be better institutional arrangement in terms of informal democracy. It promises room for any organization able to mobilize support and, thus, assets. Furthermore, "lob- 
bies never gain influence once and for all in the way in which an organization can get included permanently in a tripartite council."

The latter arguments speak obviously against the corporatist practice of coordination as such. However, the alternative arrangement is neither free from controversy. Is the rule "voice for those with assets" democratic indeed? Ottaway (2001, p. 17) indicates that "assets" need not be necessarily economic assets, and concludes: "Corporations have greater financial power, but NGOs networks can mobilize powerful constituencies - if they indeed speak for more than themselves."

\section{Pluralist Pattern for the UE?}

In the early 1990's in their influential paper Phillippe Schmitter and Wolfgang Streeck (1991) specified background conditions that made them skeptical about the re-emergence of neo-corporatism and concluded that no such pattern would emerge at the European Commission (EC) level. They argued that lower growth and higher unemployment made labour markets the loser and made employers more powerful ${ }^{5}$. Moreover, integrated European market left less room for discretionary national economic policies, making governments a less attractive target; therefore incentives to organize collectively and to bargain got reduced. At the EC level, Schmitter and Streeck pointed to an imbalance among employers and trade unions due to the focus on market integration ${ }^{6}$. Moreover, multitude of access points to the EC invited to less centralized and more fragmented lobbying. These observations led them to conclusion that at European level pluralist pattern of interest intermediation is more likely to be established than corporatist framework is (Eising 2008a; Charrad 2007). One more argument for the transformation from "national corporatism to transnational pluralism", as predicted by Schmitter and Streeck, should be mentioned. Namely, there is no "strong state" neither authoritative decision-making centre at the top, on which any corporatist system is based. The EU, and the EC in particular, lacks fiscal powers. Therefore, there is no use for interests to fuse into encompassing powerful associations (Kohler-Koch, 1997 pp. 4-5). It must be noted that this strand of reasoning is contested (see Falkner 1997), which means that controversy

\footnotetext{
${ }^{5}$ Other scholars put the problem of ailing corporatist pattern much more radically. For instance, according to Gobeyn (1993) "contemporary economic realities....make corporatism largely unnecessary. Market forces alone can presently achieve labour discipline and wage demand moderation." (Molina, Rhodes 2002, pp. 313-314).

${ }^{6}$ Actually, during the late 1970s and the 1980s in connection with the Single Market project lobbying of individual big firms widespread and seems to be more effective than before (Cini 2007, p. 285; Eising 2008b).
} 
about corporatist settings and practices in the international environment of the European Union reported in the previous section refers to corporatist channels within the EU as well.

However, the findings referred to do not imply that channels of access to European institutions tend towards pluralist either network patterns. According to Beate Kohler-Koch $(1997$, p. 2), no embracing pattern should be expected or, in other words, "no convergent system of European interest intermediation will emerge". First of all, she puts it clear that both concepts, (neo)corporatism as well as pluralism, offer deficient framework because they are intricately linked to the nation state. She observes, "[t]he European Union is no such state and it is highly unlikely that it will acquire its most prominent features in the coming future. To understand what are the characteristics of the European system and what kind of governance will be dominant in the European context, we have to look for a new conceptional framework that goes beyond our traditional models of the democratic nation state."(Kohler-Koch 1997, p. 5). The institutional setting of the EU runs counter to any uniform system of interest intermediation for two reasons. First, transformation of European institutions remains dependent on the persistence of national institutional constellations. Path dependence matters, which in this respect means "established institutional systems and practices of interest intermediation, of traditional modes of behaviour, and of the accumulated capital of mutual trust in and experience with existing relationships among members."(Kohler-Koch 1997, p.5). The variety of such formative forces suggests a dynamic and non-uniform outcome. Secondly, along with national institutional variety "the predominant norm orientation and self-understanding of the actors involved" should be taken into account (Kohler-Koch 1997, p. 6). In other words, the dimension of "shared interests in a particular subject matter and shared preferences for what is considered to be an adequate solution to a given political problem" plays a role (KohlerKoch 1997, p. 14).

The answer of the scholars engaged in the dispute is far from being ultimate and unilateral. The debate is on and this is not the aim of this survey to go in depth. The most agreeable stance seems to be contained in the following opinion: "The combination of an institutionalized inclusion of organized interests in the policy making process, on the one hand, and a looser cooperation of interest coalitions, on the other hand, is particularly eminent in the EU."(Hassel 2010, p. 160). The latter of the two observations refers to increasing fragmentation of European interest representation, which means the proliferation of narrow sector interests, the mushrooming representation of big companies, and multitude of commercial lobbyists (Koch-Kohler 1997, p. 4). The system will be pluralist in the sense of remaining fragmented. 


\section{Conclusions}

Normally, corporatism is seen as a tripartite setting and a process of peak negotiations between public authority, "social" interest representation, and private/business interest representation. The narrative of the paper reflected the evolution of this institutional arrangement from "national" to "global" corporatism. Originally, in national version governments, trade unions, and business and/or professional associations played roles respectively. In global dimension, international organizations, EU included, overtook the role of the public agent, NGOs became widely associated with "social" interests, and business became represented to much extent by transnational corporations. A final point to be made here is that in this framework the European Union can be seen consequently as a "hybrid" tripartite setting, where member governments and supranational institutions in the "public" segment, trade unions and NGOs in the "social" segment, and business associations and transnational businesses in the "private" segment can be seen.

This tripartite arrangement, though evolving, remains still valid as a device for inclusion of organized interests, but corporatists systems erode. Peak interest organizations seem to lose their relevance, especially in the "social" segment, and are said to be a sine qua non of corporatism no more. Moreover, formalized social bargaining seems to be losing as compared to ad-hoc policy networks and individual lobbying.

The subject was presented in three steps. The concept of corporatism was introduced in section 1, and the evolution of both the concept and practice was described in the two following sections. Section 2 surveyed the evolution of corporatist settings and practices (e.g. from national to global) in the international environment of the European Union. Section 3 provided an insight in the Community itself. The division has been made for academic purpose. In real world it is clear that the development of national corporatisms in member-states, drafted here at first, was relevant for European integration as much as corporatist pattern of interest intermediation, practiced within European structures, discussed next.

This brief survey concludes that the erosion (or transformation) of "neocorporatist" forms of inclusion is visible, both in national and "European" dimensions. However, no embracing pattern in the EU should be expected in its stead; on the contrary, increasing fragmentation of lobbying is observed. These findings can contribute to concerns about transparency, democracy and rent seeking within the process of European integration which need, however, a separate elaboration (e.g. see Cini 2007, p. 292). 


\section{References}

Boerzel T. (1998), Organizing Babylon - on the Different Conceptions of Policy Networks, "Public Administration", Vol. 76, No. 2, http://dx.doi.org/10.1111/14 67-9299.00100.

Charrad K. (2007), Lobbying the European Union, Nachwuchsgruppe Europaeische Zivilgesellschaft, Westfallische Wilhelms-Universitaet Muenster.

Cini M. (ed.) (2007), Unia Europejska. Organizacja i funkcjonowanie, Polskie Wydawnictwo Ekonomiczne, Warszawa.

Ebbinghaus B., Hassel A. (2000), Striking deals: concertation in the reform of European welfare states, "Journal of European Public Policy", Vol. 7, No. 1, http://dx.doi.org/10.1080/135017600343269.

Eising R. (2008a), Clientelism, Committees, Pluralism and Protests in the European Union: Matching Patterns?, "West European Politics", Vol. 31, No. 6, http://dx.doi.org/10.1080/01402380802372647.

Eising R. (2008b), Interest groups in EU policy-making, "Living Reviews in European Governance", Vol. 3, http://dx.doi.org/10.12942/lreg-2008-4.

Eising R., Kohler-Koch B. (eds) (1999), The Transformation of Governance in the European Union, London.

EU (2010), Consolidated Version of the Treaty on European Union, "Official Journal of the European Union", 30 March, http://eur-ex.europa.eu/LexUriServ/Lex UriServ.do?uri=OJ:C:2010:083:0013:0046:en:PDF (22.03.2013).

Falkner G., (1997), The Transformation of Governance in the EU: Dilemmas of Corporatism, Paper prepared for the Workshop "Transformation of Governance", January, Mannheim.

Gobeyn M.J. (1993), Explaining the decline of macro-corporatist political bargaining structures in advanced capitalist societies, "Governance", Vol. 6, No. 1. Hassel A. (2010), Multi-level governance and organized interests [in:] Zürn M., Enderlein H., Wälti S. (eds.), Handbook of Multi-Level Governance, Cheltenham, Northampton, MA: Edward Elgar.

Johnson P.M. (2005), Pluralist theory [in:] A Glossary of Political Economy Terms, Department of Political Science, 7080 Haley Center, Auburn University, Auburn, AL 36849, http://www.auburn.edu/ johnspm/gloss/pluralist theory (22.03.2013).

Kohler-Koch B. (1997), Organized Interests in the EC and the European Parliament, "European Integration online Papers", Vol. 1 No. 9, http://dx.doi.org/10.21 39/ssrn.302669.

Michalowitz I. (2004), Two-way Strategy: Interest Intermediation or Mutual Instrumentalisation? [in:] Warntjen A., Wonka A. (eds.), Governance in Europe. The Role of Interest Groups, Nomos Verlagsgesellschaft, Baden-Baden.

Molina O., Rhodes M. (2002), Corporatism: The Past, Present, and Future of a Concept, "Annual Review of Political Science", Vol. 5, No. 1, http://dx.doi.org /1.146/annurev.polisci.5.112701.184858.

Nugent N. (2012), Unia Europejska, Wydawnictwo Uniwersytetu Jagiellońskiego, Kraków. 
Ottaway M. (2001), Corporatism goes global: International organizations, nongovernmental organizations networks, and transnational business, "Global Governance", Vol. 7, No. 3.

Polanyi K.P.(2001), The Great Transformation. The Political and Economic Origins of our Times, Beacon Press, Beacon Hill.

Rymsza M. (1998), Urynkowienie państwa czy uspołecznienie rynku? Kwestia socjalna w Trzeciej Rzeczpospolitej na przykładzie ubezpieczeń społecznych, Wydawnictwo TEPIS, Warszawa.

Streeck W., Schmitter P. (1991), From National Corporatism to Transnational Pluralism: Organized Interests in the Single European Market, "Politics \& Society", Vo. 19, No. 2, http://dx.doi.org/10.1177/003232929101900202. 